\title{
Microbial Activity and Cellulose Degraders in Termite Mound Soil
}

\author{
S. Subi and A. Merline Sheela* \\ Centre for Environmental Studies, Anna University, Chennai, Tamil Nadu, India - 600025 \\ *Corresponding author
}

\section{A B S T R A C T}

\begin{tabular}{|l|}
\hline K e y w o r d s \\
Microbial Activity, \\
Cellulose \\
$\begin{array}{l}\text { Degraders, } \\
\text { Termite Mound Soil }\end{array}$ \\
\hline Article Info \\
\hline $\begin{array}{l}\text { Accepted: } \\
\text { 20 June 2020 } \\
\text { Available Online: } \\
\text { 10 July 2020 }\end{array}$ \\
\hline
\end{tabular}

\section{Introduction}

Termites are the important soil fauna often considered as soil engineers because they are playing an important role in soil forming processes (Jouquet et al., 2016). The occurrence of termite mound is normally found to be in lateritic landscapes of tropical and subtropical regions (Levick et al., 2010). Stability, resistant to erosion (Jouquet et al., 2004), nutrient and mineral richness are the important characteristics of termite mounds (Kebede, 2004). The mounds possess distinct morphology compared with the surrounding soil (Abe et al., 2009). Further, the mounds help to modify the physico chemical characteristics of the soil (Jouquet et al., 2016, Bera et al., 2020).
The termite mound soils are made up of $\mathrm{SiO}_{2}$, $\mathrm{Fe}_{2} \mathrm{O}_{3}, \mathrm{Al}_{2} \mathrm{O}_{3}$ (Momah and Okieimen, 2020). It is reported that the mound soil harbored plenty of bacterial species because of the high nutrient content (Enagbonma and Babalola, 2019). Moreover, soil nutrients are accumulated in a termite mound which is important for the ecosystem functioning (Menichetti et al., 2014). Microbial abundance and activity are key indicators for soil quality and measured by different methods (Lori et al., 2017). Dehydrogenases belong to oxidoreductase enzymes group used as an indicator of overall soil microbial activity (Garau et al., 2019). They are occurring within the microbial cells and mediating organic matter degradation (Wolinska et al., 2015) and functioning as an 
indicator of soil microbial metabolic activities (Alef and Nannipieri, 1995). Cellulose is one of the important biological compounds found abundantly on the Earth (Beguin and Aubert, 1994). Further, cellulose degrading microorganisms including aerobic and anaerobic bacteria, fungi and actinomycetes are abundant in nature (Jaishree et al., 1985). Termites are playing a key role in degrading the cellulose present in the wood and organic matter in the soil (Nakashima et al., 2002). Hence, the present study was conducted to investigate the bacterial population, the dehydrogenase enzyme activity and the presence of cellulose degrading organisms in termite mound soil found nearby.

\section{Materials and Methods}

\section{Collection of termite mound soil samples}

Samples were collected from two termite mounds present in Anna University campus, Chennai, Tamil Nadu, India located at $13.04^{\circ} \mathrm{N}$ and $80.17^{\circ} \mathrm{E}$. The soil type of the region is clay with tropical wet and dry climate. The average annual rainfall is $1,400 \mathrm{~mm}$. The termite mound from which the samples were collected is shown in Figure 1.

The termite mound soil was collected from middle position of the mound $(50 \mathrm{~cm}$ and 30 $\mathrm{cm}$ from the top for Termite mound 1 and 2 respectively). Two samples (100g) were collected from each mound, air dried, sieved through a $2 \mathrm{~mm}$ sieve, packed in labeled cover and stored at $4^{\circ} \mathrm{C}$ for further analysis (Bera et al., 2020).

\section{Characterization of termite mound soil}

The $\mathrm{pH}$ of the soil was measured in the ratio of 1: 2.5(soil: water). After shaking the mixture in an orbital shaker at 160rpm for 30 minutes, allowed for 30min. $\mathrm{pH}$ was measured by $\mathrm{pH}$ meter (Elico LI 120) equipped with combined glass-calomel electrode. The Electrical Conductivity was measured by Digital conductivity meter (Labline) (Jackson 1973). The moisture content of the soil was determined based on (ASTM D2216- 10, 1998). The total organic carbon (TOC) content of the soil was determined by wet oxidation method (Wakley and Black, 1934). The Total Kjeldahl Nitrogen (TKN) was determined following the procedure of Lee et al., (1996).The phosphorus $(\mathrm{P})$ was estimated by extraction of $1.0 \mathrm{~g}$ of sample with $50 \mathrm{ml}$ of ammonium fluoride solution. To $5 \mathrm{ml}$ of filtered extract 4 $\mathrm{ml}$ of ascorbic acid reagent was added, volume was made up to $10 \mathrm{ml}$ and readings were taken in a Spectronic $20 \mathrm{D}+$ Spectrophotometer at $690 \mathrm{~nm}$ and the available $\mathrm{P}$ was calculated using $\mathrm{K}_{2} \mathrm{HPO}_{4}$ as standard (Olson et al., 1954). Available potassium $(\mathrm{K})$ was estimated with neutral ammonium acetate $(200 \mathrm{ml})$ extraction of termite mound soil in a flame photometer. Values were calculated from $\mathrm{KCl}$ standard (Sankaram, 1966).

\section{Dehydrogenase enzyme activity}

The procedure of Alef and Nannipieri, 1995 was followed to determine the dehydrogenase enzyme activity. About $6 \mathrm{~g}$ of soil was taken in $50 \mathrm{ml}$ serum vials, added with $0.2 \mathrm{~g} \mathrm{CaCO}_{3}$ and thoroughly mixed. The contents of vials were fully saturated to 100 percent Water Holding Capacity (WHC) by adding $1 \mathrm{ml}$ of 3.0 percent aqueous solution of TriphenylTetrazolium Chloride (TTC), $1.0 \mathrm{ml}$ of 1.0 percent sucrose solution and $2.5 \mathrm{ml}$ of distilled water. The vials were sealed and incubated at $37{ }^{\circ} \mathrm{C}$ for $24 \mathrm{~h}$. The TriphenylFormazon (TPF) formed in each sample was extracted with hot methanol by filtration. The filtration was done until the red color disappeared and the volume was adjusted to $100 \mathrm{ml}$ by adding methanol. The intensity of the red color of the filtrate for 
each sample was measured at $485 \mathrm{~nm}$ in a Spectrophotometer (Shimadzu UV 1280) using methanol as a blank. The concentrations of Formazon for each sample (i.e., dehydrogenase activity) were determined by referring to a standard curve of the TriphenylFormazon (TPF) in methanol and expressed as $\mathrm{mg} / \mathrm{g} / \mathrm{h}$ of the sample.

\section{Cellulose degrading bacteria}

Initially, the bacterial species were isolated from the termite mound soil by serial dilution (up to $10^{-7}$ ) and plating method(Singh et al., 2013) in cellulose agar medium composed of $\mathrm{KH}_{2} \mathrm{PO}_{4} 0.5 \mathrm{~g}, \mathrm{MgSO}_{4} 0.25 \mathrm{~g}$, cellulose 2.0g, Agar $15 \mathrm{~g}$, gelatin $0.2 \mathrm{~g}$, distilled water $1000 \mathrm{ml}$ and pH 6.8 - 7.2) (Gupta et al., 2012). After incubating the plates at $37^{\circ} \mathrm{C}$ for $48 \mathrm{~h}$ the colonies were counted and expressed in Colony Forming Units (CFU)/g soil (dry weight basis). The isolated colonies were purified with repeated sub culturing and tested for the presence of cellulose degraders. Subsequently Gram staining (Gram, 1884) was performed to know the type of isolated bacterial species.

Finally, the cellulose degrading ability was confirmed by culturing the isolated bacterial species in Congo red agar medium (Gupta et al., 2012) $\left(\mathrm{KH}_{2} \mathrm{PO}_{4} 0.5 \mathrm{~g}, \mathrm{MgSO}_{4} 0.25 \mathrm{~g}, \mathrm{CMC}\right.$ cellulose (Sigma Aldrich) 2.0g, Agar $15 \mathrm{~g}$, Cong red $0.2 \mathrm{~g}$, gelatin $0.2 \mathrm{~g}$, distilled water $1000 \mathrm{ml}, \mathrm{pH}$ 6.8). After $96 \mathrm{~h}$ of incubation at $37^{\circ} \mathrm{C}$ the cellulose decomposition was observed by measuring the diameter of the clearing zone around the colony and expressed in millimeter ( $\mathrm{mm})$.

\section{Results and Discussion}

The soils collected from the termite mound were characterized and the results are presented in Table 1. The $\mathrm{pH}$ of the samples collected from termite mounds 1 and 2 was found to be 8.1 and 8.2 respectively. The Electrical conductivity (EC) of the termite mound soils 1 and 2 was 0.22 and $0.15 \mathrm{mS} / \mathrm{cm}$ respectively. The total organic carbon (TOC) content was 16.80 and $28.40 \mathrm{~g} / \mathrm{kg}$ for the two samples. The nitrogen (N) (19.60 and 21.20 $\mathrm{g} / \mathrm{kg})$, phosphorus $(\mathrm{P})(10.2$ and $9.76 \mathrm{~g} / \mathrm{kg})$ and potassium $(\mathrm{K})(26.57$ and $10.03 \mathrm{~g} / \mathrm{kg})$ contents were analysed for the samples collected from the two termite mounds.

\section{Dehydrogenase enzyme activity}

The dehydrogenase enzyme activity of the termite mound soil collected from the Anna University campus was estimated and the results are given in Table 2.

The dehydrogenase enzyme activity of the termite mound soil collected from Anna University campus was found to be 25 and $23 \mathrm{mgTPF} / \mathrm{g} / \mathrm{h}$ respectively for termite mound 1 and 2.

\section{Cellulose degrading bacterial population}

The cellulose degrading bacterial population in termite mound soils was shown in Figure 2

The cellulose degrading bacterial colonies of termite mound 1 was found to be $25 \times 10^{6}$ CFU /g soil (dry weight basis) and that of the termite mound 2 was $20 \times 10^{6} \mathrm{CFU} / \mathrm{g}$ soil (dry weight basis).

\section{Cellulose degrading ability}

The termite mound soils collected from Anna University campus, Chennai, Tamil Nadu India was analyzed for the presence of cellulose degrading bacterial species. The clearing zones observed in the Carboxy Methyl Cellulose (CMC) Agar medium indicating the presence of cellulose degraders (Figure 3). 
Table.1 Characteristics of Termite mound soil

\begin{tabular}{|c|c|c|}
\hline \multirow{2}{*}{ Parameters } & \multicolumn{2}{|c|}{ Values * } \\
\cline { 2 - 3 } & $\begin{array}{c}\text { Termite } \\
\text { mound soil 1 }\end{array}$ & $\begin{array}{c}\text { Termite } \\
\text { mound soil 2 }\end{array}$ \\
\hline $\mathbf{p H}$ & 8.1 & $\mathbf{8 . 2}$ \\
\hline $\mathbf{E C}(\mathbf{m S} / \mathbf{c m})$ & 0.22 & $\mathbf{0 . 1 5}$ \\
\hline TOC(g/kg) & 16.80 & $\mathbf{2 8 . 4 0}$ \\
\hline $\mathbf{N}(\mathbf{g} / \mathbf{k g})$ & 19.60 & $\mathbf{2 1 . 0 0}$ \\
\hline $\mathbf{P}(\mathbf{g} / \mathbf{k g})$ & 10.23 & $\mathbf{9 . 7 6}$ \\
\hline $\mathbf{K}(\mathbf{g} / \mathbf{k g})$ & $\mathbf{2 6 . 5 7}$ & $\mathbf{1 6 . 0 3}$ \\
\hline
\end{tabular}

*values represent mean of 3 determinations

Table.2 Dehydrogenase enzyme activity of termite mound soil

\begin{tabular}{|c|l|c|}
\hline S. No & Samples & $\begin{array}{c}\text { Dehydrogenase enzyme activity* } \\
\text { (mgTPF/g/h) }\end{array}$ \\
\hline 1. & Termite mound 1 & 25 \\
\hline 2. & Termite mound 2 & 23 \\
\hline
\end{tabular}

*values represent mean of three determinations

(TPF - TriphenylFormazon)

Fig.1 Termite mounds [(A) Termite mound 1 (B) Termite mound 2] found in Anna University Campus, Chennai (Red arrow indicates the position of sampling)
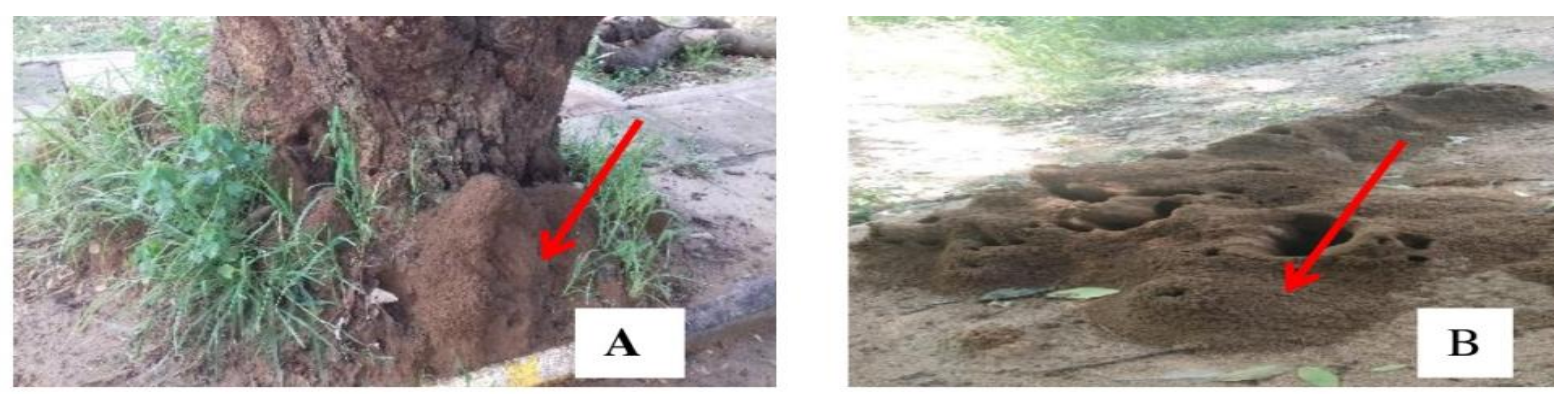

Fig.2 Cellulose degrading bacterial colonies isolated from termite mound soils (Anna University campus, Chennai, Tamil Nadu, India),
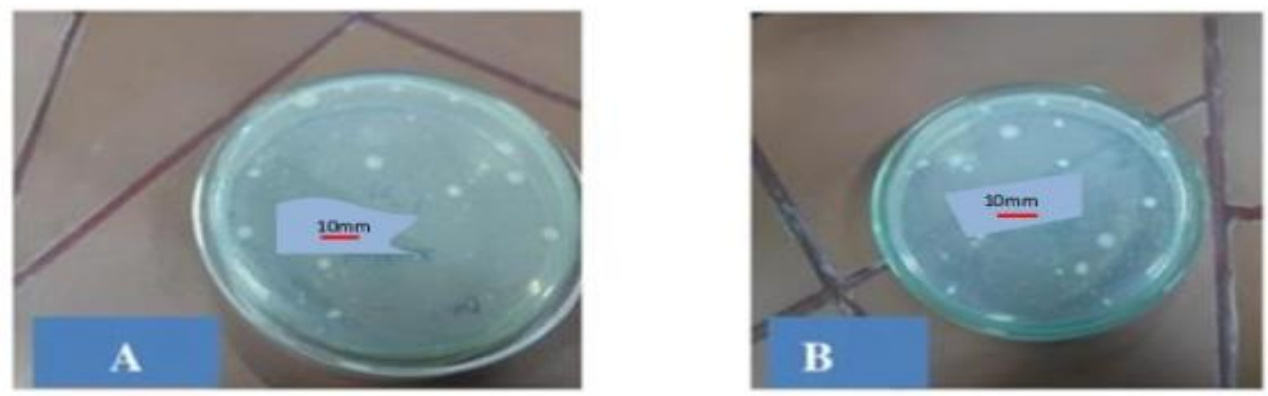

[(A) Termite mound $1\left(25 \times 10^{6} \mathrm{CFU} / \mathrm{g}\right.$ soil $)(B)$ Termite mound $2\left(20 \times 10^{6} \mathrm{CFU} / \mathrm{g}\right.$ soil $\left.)\right]$ CFU - colony forming units 
Fig.3 Plates showing clearing zones in Carboxy Methyl Cellulose (CMC) agar indicating the presence of cellulose degraders (Green arrows indicate the clearing zones $(10 \mathrm{~mm})$ formed by cellulose degraders

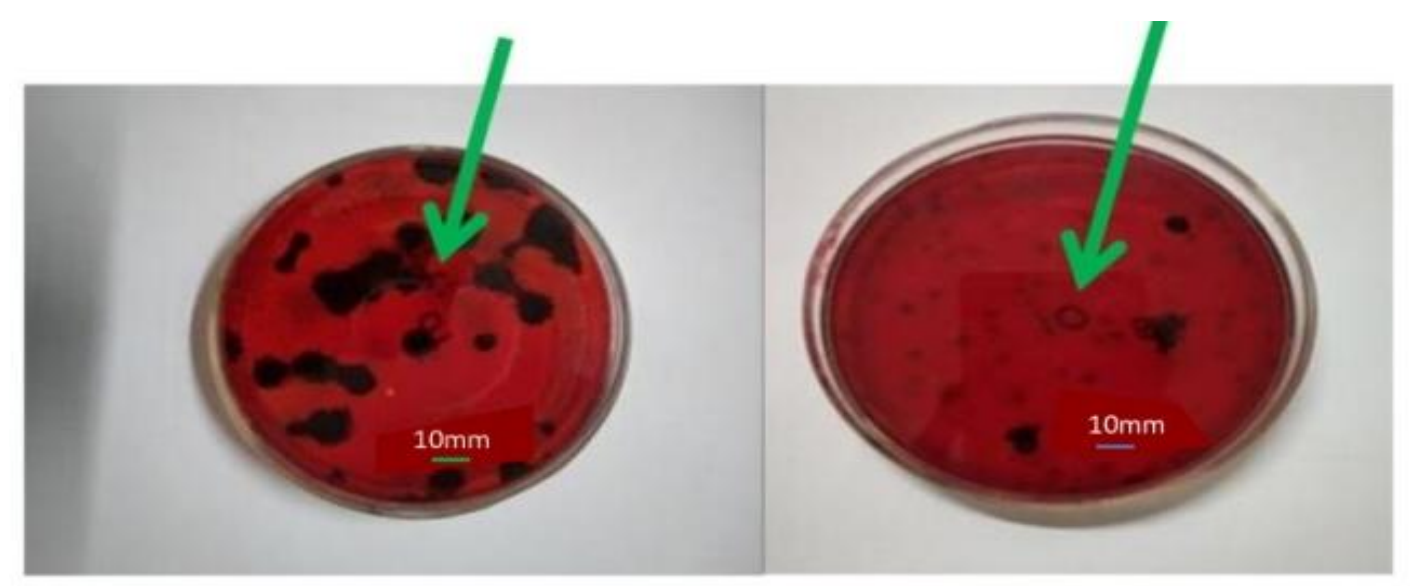

Fig.4 Photomicrograph of Gram negative cells obtained from termite mound soil (100x)

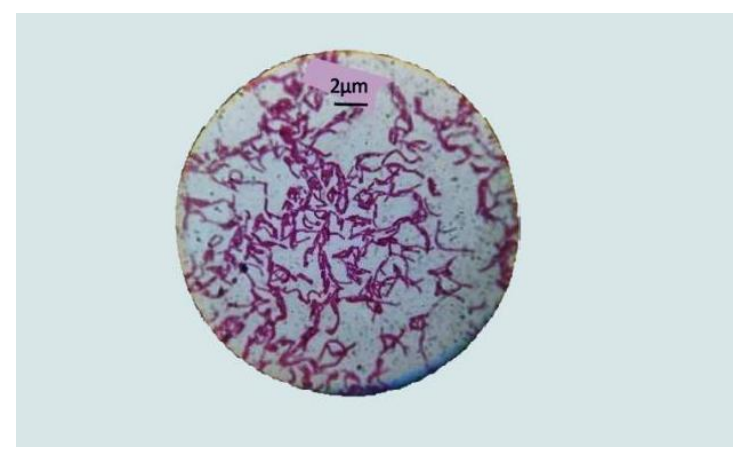

Further, Gram staining was done to check whether the isolated bacterial species were gram negative or gram positive. On staining, the bacterial cells obtained from the termite mound soil were found to be Gram negative (Figure 4).

In nutrient poor soils termite plays important role in nutrient cycling (Avitable et al., 2016, Lima et al., 2018). This might be the reason for higher $\mathrm{N}$ and $\mathrm{P}$ contents of the termite mound soils. Further, it has been reported that the $\mathrm{P}$ content of the termite mound soil is higher than the surrounding soil, due to the incorporation of feces in the mound material (Lopez-Hernandez et al., 2006). Moreover, the mounds are having more clay content, which is preventing the loss of $\mathrm{P}$ (Oliveira et al., 2012). Soil binding enzymes have been extracted from the termite mound soils (Pariyarath, 2014). Among the oxidoreductases class of enzymes, dehydrogenases is the key enzyme indicating the overall microbial activity of the soil (Salazar et al., 2011). Further, the organic matter decomposition in soil is achieved by these enzymes (Zhang et al., 2019). The dehydrogenase enzyme activity of the fertile soil was found to be $>30 \mathrm{mg} \mathrm{TPF} / \mathrm{g} / \mathrm{h}$ (Kumar et al., 2013), while in the termite mound soil collected from the Anna University campus it was 25 and $23 \mathrm{mgTPF} / \mathrm{g} / \mathrm{h}$ indicating the microbial diversity and microbial activity in termite mound soils. The presence of cellulase 
enzyme in the termite mound soil was observed by the formation of clearing zones in agar medium supplemented with CMC. Normally termites are feeding on organic matter rich in cellulose. The bacterial population in termite mound soil is found to be more (up to $10^{6} \mathrm{CFU} / \mathrm{g}$ sample) (Keya et $a l ., 1982)$ and the major group is cellulose decomposers (Varma et al., 1994). Furthermore, most recently a plant cell wall degrading enzyme has been reported in gut micro biomes of Neotropical termite species (Victorica et al., 2020).

The bacterial species isolated from the termite mound soils were found to be Gram negative. It has been already demonstrated that in addition to gram positive bacterial species termite gut and mound soil harbored gram negative species (Ramin et al., 2008).

From this study it is concluded that the dehydrogenase enzyme activity was 25 and $23 \mathrm{mg} \mathrm{TPF} / \mathrm{g} / \mathrm{h}$ respectively for the two samples analyzed. Further, the bacterial population was 25 and 20CFU/g soil (dry weight basis). The clearing zones with the diameter of $20 \mathrm{~mm}$ in CMC agar plates indicated the cellulose degrading ability of the bacterial species obtained from the study area. The cellulose degraders were found to be Gram negative bacterial species. However, a thorough study is required to investigate the microbial diversity and microbial enzymes present in termite mound soils available in different regions.

\section{References}

Abe, S. S., Yamamoto, S. and Wakatsuki, T. 2009. Soil-Particle Selection by the Mound-Building Termite Macrotermesbellicosus on a Sandy Loam Soil Catena in a Nigerian Tropical Savanna, Journal of Tropical Ecology, 25(4): 449-452.
Alef, K and Nannipieri, P. 1995. Protease activity In: Methods in Applied Soil Microbiology and Biochemistry, Elsevier Publishing Pvt.Ltd, P. 608.

ASTM D 2216-10. 1998. Standard test Methods for Laboratory Determination of Water(Moisture) content of soil and Rocky mass, Philadelphia: American Society of testing and Materials.

ASTM D 2216-10. 1998. Standard test Methods for Laboratory Determination of Water(Moisture) content of soil and Rocky mass, Philadelphia: American Society of testing and Materials.

Avitabile, S. C., Nimmo, D.G., Bennett, A. F, Clarke, M. F. 2015. Termites are resistant to the effects of fire at multiple spatial scales. PLoS ONE. 10:e0140114.

Beguin, P. and Aubert, J.P. 1994. The biological degradation of cellulose. FEMS Microbiology Reviews, 13: 25-58.

Bera, D., Bera, S. and Chatterjee, N. D. 2020. Termite mound soil properties in West Bengal, India.Geoderma Regional, 22:

e00293. doi:10.1016/j.geodrs.2020.e002 93.

Enagbonma, B.J. and Babalola, O. O. 2019. Potentials of termite mound soil bacteria in ecosystem engineering for sustainable agriculture. Annals of Microbiology, 69: 211-219.

Garau, G., Porceddu, A., Sanna, M., Silvetti, M. and Castaldi, P. 2019. Municipal solid wastes as a resource for environmental recovery : Impact of water treatment residuals and compost on the microbial and biochemical features of As and trace metal - polluted soils. Ecotoxicology and Environmental Safety, 174(15): 445 - 454.

Gram, H.C1884.Über die isolierteFärbung der Schizomyceten in Schnitt- und Trockenpräparaten (in German). 
Fortschritte der Medizin, 2: 185-189.

Gupta, P., Samant, K. and Sahu, A. 2012.Isolation of cellulose - degrading bacteria and determination of their cellulolytic potential. International Journal of Microbiology, doi:10.1155/2012/578925.

Jackson, M.L. 1973. Soil Chemical Analysis.Prentice Hall of India Pvt. Ltd., New Delhi, 498.

Jaishree, P., Aditi, S. and Ajit, V. 1985. Cellulose digesting bacteria from live termite mound soils. Current Science, 54(21): 1098 - 1101 .

Jouquet, P., Tessia, D. and Lepage, M. 2004. The soil structural stability of termite nests: role of clays in Microtermesbellicosus(Isoptera,Macrote rmitinae) mound soils.European Journal of Soil Biology, 40: 23 - 29.

Jouquet, P., Nicolas, B., Rashmi, S., Thomas, B., Saran, T., Shahid Abbas, A. 2016. Termites The Neglected Soil Engineers of Tropical Soils, Soil Science, 181(3): 157-165.

Kebede, F. 2004. Use of termite mounds in geochemical exploration in North Ethiopia. Journal of African Earth Sciences, 40(1):101-103.

Keya, S.O., Mureria, N.K. and Arshad, M.A. 1982. Population dynamics of soil microorganisms in relation to proximity of termite mounds in Kenya. J. Arid. Environ. 5, 353-359.

Kumar, S., Chanduri, S. and Maiti, S. K. 2013. Soil dehydrogenase enzyme activity in natural and mine soil - A review. Middle - East Journal of Scientific Research, 13(7):898 - 906.

Levick, S. R., Asner, G. P., Bowdoin, T. K. and Knapp, D. E. 2010. The spatial extent of termite influences on herbivore browsing in an African Savanna. Biological Conservation, 143(13): 2462 $-2467$.

Lima, S.S., Pereira, M.G., Pereira, R.N.,
Pontes, R.M. and Rossi, C.Q. 2018. Termite mounds effects on soil properties in the Atlantic Forest biome. Rev Bras Cienc Solo. 42:e0160564.

Lee, D., Nguyen, V. and Littlefield, S. 1996.Comparison of methods for determination of nitrogen levels in soil, plant and body tissues and water. Communications in Soil Science and Plant Analysis, 27(3 - 4): 783 - 793.

López-Hernández, D., Brossard M, Fardeau, J. C. and Lepage, M. 2006. Effect of different termite feeding groups on $\mathrm{P}$ sorption and $\mathrm{P}$ availability in African and South American savannas. Biology and Fertility of Soils,42:207-14.

Lori, M., Symnaczik, S., Ma"der, P., De Deyn, G. and Gattinger, A. 2017. Organic farming enhances soil microbial abundance and activity-A meta analysis and meta-regression. PLoS One, $\quad$ 12(7): $\quad$ e0180442. https://doi.org/10.1371/journal. pone. 018044253 .

Menichetti, L.; Landi, L.; Nannipieri, P.; Katterer, T.; Kirchmann, H. and Renella, G. 2014. Chemical properties and biochemical activity of colonized and abandoned litter-feeding termite (Macrotermesspp.) mounds in chromic Cambisol Area on the Borana Plateau, Ethiopia.Pedosphere, 24: 399-407.

Momah, M. and Okieimen, F. E. 2020.Minerology, geochemical composition and geotechnical properties of termite mound soil. Journal of Ecology and the Natural Environment, 12(1): $1-8$.

Nakashima, K., Watanabe, H., Saitoh, H., Tokuda, G. and Azuma, J. I. 2002. Dual cellulose-digesting system of the woodfeeding termite, CoptotermesformosanusShiraki. Insect Biochemistry and Molecular Biology, 32(7): 777 - 784.

Oliveira, L.B.T., Santos, A.C., Silva Neto, 
S.P., Silva, J. E. C. and Paiva, J. A. 2012. Alteraçõesfísicas e químicas do solo emvirtude de construçõestermíticas no norte de Tocantins. Eng Agricul.2 (20) :118-30.

Olsen, S. R., Cole, C. V., Watanabe, F. S. and Dean. L. A. 1954. Estimation of available phosphorus in soils by extraction with $\mathrm{NaHCO}_{3}$, USDA Cir.939.U.S. Washington.

Pariyarath, P. N. 2014. Extraction and Biochemical Studies of Soil Binding Proteins from Termite Mound. International Journal of Chem Tech Research, 6(14): 573 - 5739.

Ramin, M., Alimon, A. P., Abdullah, N., Panandam, J. M. and Sijam, K. 2008. Isolation and identification of three species of bacteria from the termite Captotermescurvignathus (Holmgren) present in the vicinity of University Putra Malaysia. Research Journal of Microbiology, 3(4): 288 - 292.

Salazar, S., Sánchez, L. E., Alvarez, J., Valverde, A., Galindo, P., Igual, J. M. and Santa-Regina, I. 2011. Correlation among soil enzyme activities under different forest system management practices. Ecological Engineering, 37(8): 1123-1131.

Sankaram, A. 1966. A Laboratory Manual for Agricultural Chemistry: Asia Publishing House, Bombay, pp.41 - 49.

Singh, S., Maholkar, V. S. and Goyal, A. 2013. Isolation, identification and characterization of a cellulolytic
Bacillus amyloliquifaciens strain SS35 from Rhinoceros dung. ISRN Microbiology, https://doi.org/10.1155/2013/728134.

Varma, A., Kolli, B. K., Paul, J., Saxena, S. and Konig, H. 1994. Lignocellulose degradation by microorganisms from termite hills and termite guts: A survey on the present state of art. FEMS Microbiology Reviews, 15: $9-25$.

Victorica, M. R., Soria, M. A., Batista-García, R. A., Ceja-Navarro, J. A., Vikram, S., Ortiz, M. and Etcheverry, C. 2020.Neotropical termite microbiomes as sources of novel plant cell wall degrading enzymes. Scientific Reports, 10(1): 1-14.

Walkley, A. and Black, I. 1934. An Examination of Degthareff method for Determining soil Organic matter and a proposed modification of the chromic acid titration method, Soil Science, 27: $29-38$.

Wolinska, A. Stepniewska, Z and Pytlak, P. 2015. The effect of environmental factors on total soil DNA content and dehydrogenase activity. Archives of Biological Sciences Belgrade, 67(2): $493-501$.

Zhang, K. P., Shi, Y., Cui, X. Q., Yue, P., Li, K. H., Liu, X. J. et al., 2019. Salinity is a key determinant for soil microbial communities in a desert ecosystem. mSystems, 4: e00225-e00218.

\section{How to cite this article:}

Subi, S. and Merline Sheela, A. 2020. Microbial Activity and Cellulose Degraders in Termite Mound Soil Int.J.Curr.Microbiol.App.Sci. 9(07): 2151-2161. doi: https://doi.org/10.20546/ijcmas.2020.907.251 